Canadian University Music Review

Canadian University Music Review

Revue de musique des universités canadiennes

\title{
The Piano Music of Percy Grainger: A Pianist's Perspective on Pedalling
}

\section{Glen Carruthers}

Volume 21, numéro 2, 2001

URI : https://id.erudit.org/iderudit/1014486ar

DOI : https://doi.org/10.7202/1014486ar

Aller au sommaire du numéro

\section{Éditeur(s)}

Canadian University Music Society / Société de musique des universités canadiennes

\section{ISSN}

0710-0353 (imprimé)

2291-2436 (numérique)

Découvrir la revue

Citer cet article

Carruthers, G. (2001). The Piano Music of Percy Grainger: A Pianist's

Perspective on Pedalling. Canadian University Music Review / Revue de musique

des universités canadiennes, 21(2), 77-93. https://doi.org/10.7202/1014486ar

\section{Résumé de l'article}

L'éminent pianiste et compositeur Percy Aldridge Grainger (1882-1961) a couvert les pages de ses arrangements de musique inédite et de chansons de folklore d'instructions détaillées, quoique idiosyncratiques, à l'intention des interprètes. Il est à la fois inhabituel et révélateur que sa technique consciencieuse de la pédale se révèle autant dans ses minutieuses directives à l'intention des pianistes. Les partitions de Grainger font ici l'objet d'un examen sous l'angle des pédales forte, de prolongation et douce. Les nombreux exemples musicaux remplissent deux objectifs : 1) ils renseignent sur la complexité de la technique de pédale de Grainger ; et 2) ils démontrent l'éventail des méthodes de notation que le compositeur a employées à divers moments de sa carrière, pour permettre aux interprètes de reproduire le plus fidèlement possible ses propres utilisations scrupuleuses de la pédale. De plus, l'examen approfondi de cet aspect particulier de la riche maîtrise de Grainger jette un éclairage sur la relation entre compositeurs et interprètes, ou notation et interprétation, que Grainger a cherché à comprendre et à énoncer toujours plus clairement au cours de sa carrière.
All Rights Reserved ( C Canadian University Music Society / Société de musique des universités canadiennes, 2002
Ce document est protégé par la loi sur le droit d'auteur. L’utilisation des services d'Érudit (y compris la reproduction) est assujettie à sa politique d'utilisation que vous pouvez consulter en ligne.

https://apropos.erudit.org/fr/usagers/politique-dutilisation/ 


\section{THE PIANO MUSIC OF PERCY GRAINGER: A PIANIST'S PERSPECTIVE ON PEDALLING}

\section{Glen Carruthers}

Percy Grainger's pianism was remarkable for, among other things, scrupulous and innovative pedalling and, as Joseph Banowetz wrote in 1985, Grainger's "ideas on pedalling still prove to be extremely advanced." Evidence of Grainger's originality in pedalling can be heard readily in his commercial recordings and pedal technique is mentioned frequently in concert reviews and other commentaries on Grainger's playing. In the opinion of John Douglas Todd, an Australian pianist who studied with Grainger, the latter "delved deeply and systematically into the expressive uses of the pedals.... His written and spoken advice on this aspect of playing was by far the most valuable and unquestionable part of his teaching."2

It is fortunate that much evidence of Grainger's unique pedalling survives in the printed editions of his music. The following article examines several of the more interesting examples of Grainger's use of the pedals in his own compositions.

\section{The DAMPer Pedal}

Two of Grainger's pupils, Laurence Dilsner and Alma Brock-Smith, agree that their teacher did not believe that the damper pedal should be used in place of legato fingering. Grainger told Dilsner that "if he [Grainger] were to again teach beginners, he would insist on six months of concentrated organ study before starting the piano. This would encourage meticulous legato fingering without having to rely on the damper pedal...."3 Of a concert in Saskatoon in 1926, Brock-Smith recalled that

the sound that [Grainger produced] convinced you that he must have had a natural legato, a vocal legato. . . . And his pedal! I wish so many people might have gone to his concerts just for that one reason. To actually look at his foot and see how he used that pedal with such reverence, never, never to accomplish what he wasn't getting with the fingers, but to enhance and to enjoy that wonderful mix of overtones. ${ }^{4}$

1 Joseph Banowetz, The Pianist's Guide to Pedaling (Bloomington: Indiana University Press, 1985).

2 John Douglas Todd, "Grainger the Pianist," Studies in Music 16 (1982): 105.

3Laurence Dilsner, "Percy Grainger (1882-1961): Some Personal Recollections," Clavier 21, no. 9 (1982): 13-14; rpt. "Grainger as Performer-Composer-Teacher" in A Source Guide to the Music of Percy Grainger, ed. Thomas P. Lewis (White Plains, N. Y.: Pro/Am Music Resources, Inc., 1991), 13.

4 Alma Brock-Smith, personal interview, 15 March 1995. 
Ironically, once legato technique had been mastered, Grainger believed it could be dispensed with. Since the damper pedal "provides a complete legato effect to the ear ...., and makes legato playing by the fingers unnecessary in most cases, the hands and fingers may (in such cases) be freely raised between notes and chords, thereby making simultaneous tone-strength differentiation and other tonal contrasts much easier to control."5

The use of the damper pedal is indicated in several different ways in Grainger's published scores, including the older stylized $P e d$. with an asterisk to indicate the point of release and the newer horizontal brackets. In Grainger's earliest published works pedal indications are sparse and, when they do occur, they show where the pedal is to be depressed (by means of the stylized Ped.) but not where it should be released. Grainger was, in the early stages of his career, apparently willing to give performers considerable interpretive latitude. The Paraphrase on Tchaikovsky's "Flower-Waltz" (Forsyth Bros., 1905) is typical in this regard. Pedalling is indicated only in the arpeggio passages in mm. 54-79, 264-289 and 362, and for a single chord in m. 375, and pedal releases are not shown (example 1).

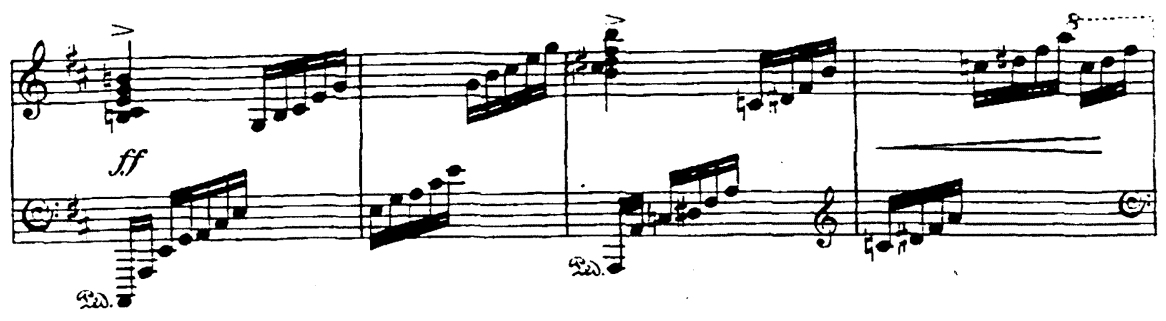

Example 1: Paraphrase on Tchaikovsky's “Flower-Waltz”, bars 264-267. Copyright (C) 1905 (renewed) by G. Schirmer, Inc. (ASCAP). International copyright secured. All rights reserved. Reprinted by permission.

It is evident contextually that the pedal is to be employed at other places throughout the work, and in pieces published within a few years of the Paraphrase, Grainger is specific when he intends otherwise. Directives such as "no pedal" and "no pedal until marked" occur at the outset of Shepherd's Hey (Schott, 1911), Molly on the Shore (Schirmer, 1918), Knight and Shepherd's Daughter (Schirmer, 1918), Spoon River (Schirmer, 1922) and Jutish Medley (Schott/Schirmer, 1928). The marking "No pedal" occurs internally in Shepherd's Hey (m. 53), "The Gum-Suckers" March (Schirmer, 1916) (m. 154), Molly on the Shore (mm. 55, 175 and 179), ${ }^{6}$ Spoon River (m. 84) and

5Percy Grainger, "Foreword" to H. Balfour Gardiner, Prelude (De Profundis) (Forsyth Bros., 1905); rpt. as Percy Grainger, Guide to Virtuosity (New York: G. Schirmer, 1923); rpt. as "Some Advice to Piano Students" in Lewis, A Source Guide to the Music of Percy Grainger, 280.

6In the published edition of Molly on the Shore what is marked as m. 5 is actually m. 6 . Accordingly, the measure numbers are off by one throughout the work. In the present paper the correct measure numbers are used. 
Eastern Intermezzo (Schirmer, 1922) (m. 98), and the player is admonished "no Pedal" six times in the course of Scotch Strathspey and Reel (Schirmer, 1939).

On the other hand, in a few works, such as The Immovable Do (Schirmer, 1940) and Harvest Hymn (Schirmer, 1940), a new pedal is called for on virtually every beat. In such instances, Grainger leaves nothing to chance. Using the stylized Ped. in The Immovable Do and horizontal brackets in Harvest Hymn, Grainger painstakingly indicates each and every pedal change (example 2).

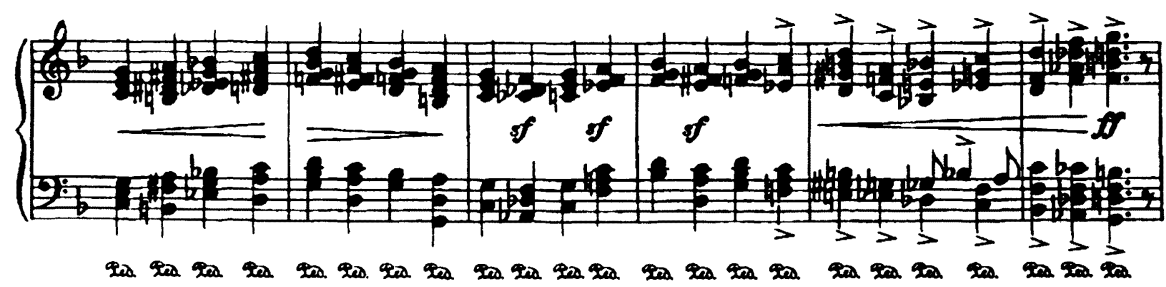

Example 2a: The Immovable Do, bars 72-77. Copyright () 1941 (renewed) by G. Schirmer, Inc. (ASCAP) International copyright secured. All rights reserved. Reprinted by permission.

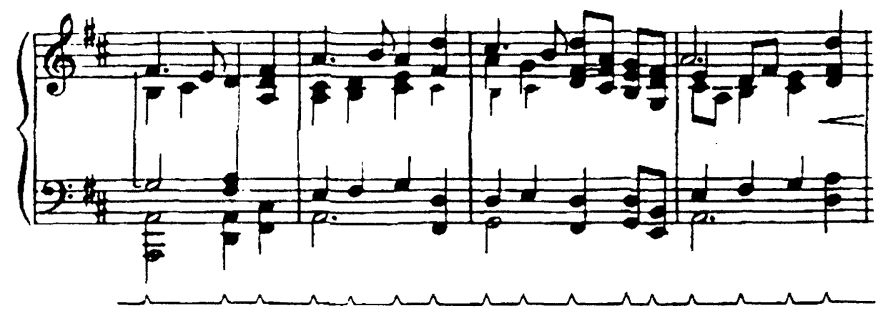

Example 2b: Harvest Hymn, bars 6-9. ${ }^{8}$ Copyright $\odot 1940$ (renewed) by G. Schirmer, Inc. (ASCAP). International copyright secured. All rights reserved. Reprinted by permission.

By the end of The Immovable Do Grainger's fastidiousness has carried over into parameters other than pedalling. In addition to copious dynamic and pedal markings, the closing measures of this work feature a wealth of idiosyncratic instructions. The directives "Slightly clingingly," "in time," "Top voice to the fore," "clingingly" (twice), "louden quickly," "slow off slightly," "slow off lots," "Lowest notes much to the fore" occur in the space of only eight measures. Clearly, by the 1940s Grainger was indulging in as few interpretive ambiguities as possible.

Indeed, Grainger's precision in pedal notation seems almost obsessive, to the extent that some of his markings seem superfluous. In Shepherd's Hey Grainger has recourse to unconventional means to notate what is in effect quite simple and usual pedalling. To indicate syncopated pedalling in $\mathrm{mm}$. 57-60,

7Unless otherwise noted, dates given are those of the first publication of the piano version of the work in question (which may be very different from the date that the work was composed and/or published in its original form).

8 In the published score, the measure numbering begins with the first measure, even though it is incomplete. 
the stylized Ped. and asterisk are placed one above the other, with a note explaining that this "means that the last pedal is to be raised just at the moment of striking the keys and pressed down again as fast as possible." By 1911 this style of pedalling had become the norm and such detailed instructions were for the most part unnecessary (example 3 ).

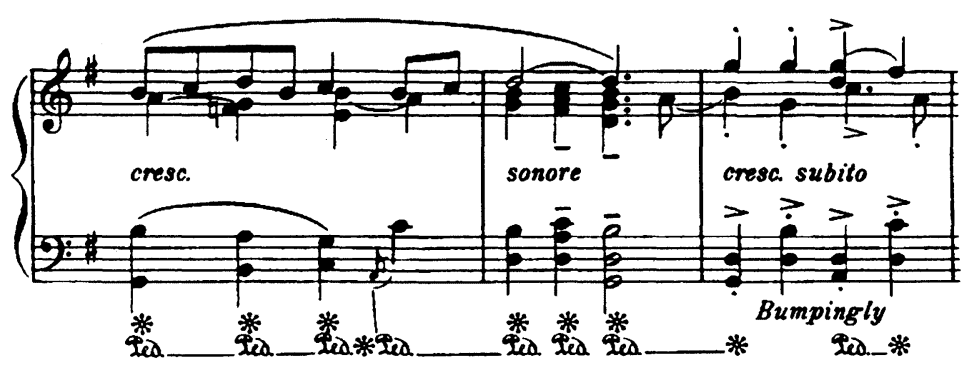

Example 3: Shepherd's Hey, bars 59-61. Copyright (C) 1915 (renewed) by G. Schirmer, Inc. (ASCAP). International copyright secured. All rights reserved. Reprinted by permission.

In conjunction with both the stylized $P e d$. and horizontal brackets, Grainger sometimes uses dotted vertical lines to indicate the moment at which the pedal is to be depressed and/or released. In this way, a clear distinction is made between rhythmic (on the beat) and syncopated or legato (just after the beat) pedalling. A vertical line in conjunction with the stylized Ped. is used to indicate the syncopated release on an offbeat in "The Gum-Suckers" "March (mm. 13-14, 61-62 and 140), Country Gardens (Schott/Schirmer, 1919) (mm. 11, 17, 21, 35, 39, 49 and 54), and Molly on the Shore (mm. 39, 43, 46, 49, 70 and 163), and the same method is used to indicate a change of pedal, rather than simply a release, in Colonial Song (Schirmer and Allan [Australia], 1921) (mm. 4, 10,11, 12, 14, 18, 25 and 35) (example 4).

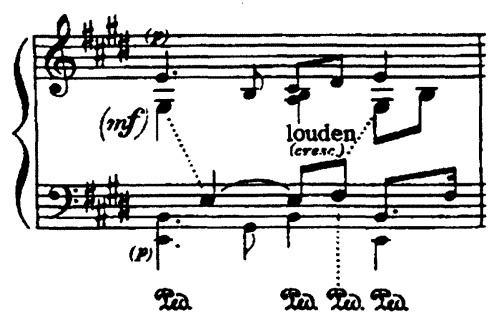

Example 4: Colonial Song, bar 4. Copyright (C) 1928 (renewed) by G. Schirmer, Inc. (ASCAP). International copyright secured. All rights reserved. Reprinted by permission.

Grainger also uses vertical dotted lines to indicate where grace notes before the beat are to be caught in the pedal (e.g. "The Gum-Suckers" March at m. 92 and in Molly on the Shore at m. 83), although the same effect is called for 
in Handel in the Strand (Schott/Schirmer, 1930) (mm. 35, 69 and 80) and vertical lines are not used (example 5).

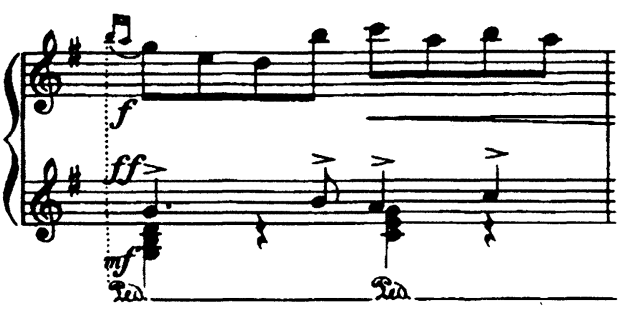

Example 5a: Molly on the Shore, bar 83. Copyright (C) 1911 (renewed) by G. Schirmer, Inc. (ASCAP). International copyright secured. All rights reserved. Reprinted by permission.

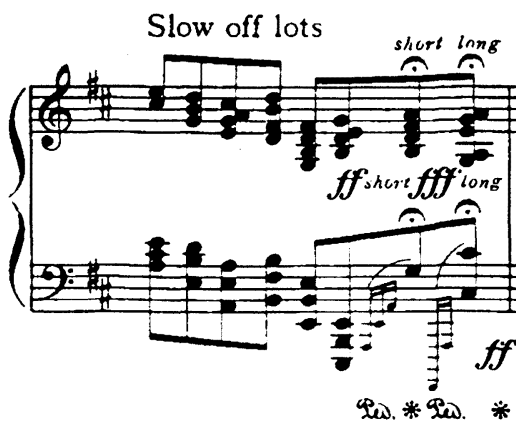

Example 5b: Handel in the Strand, bar 69. Copyright (C) 1930 (renewed) by G. Schirmer, Inc. (ASCAP). International copyright secured. All rights reserved. Reprinted by permission.

When horizontal brackets are employed, in To A Nordic Princess (Schott/ Schirmer, 1929), The Hunter in His Career (Schott/Schirmer, 1930), Harvest Hymn and Jutish Medley, pedalling can be indicated much more precisely than with the stylized Ped. Accordingly, Grainger dispenses with vertical lines. Exceptions occur in Grainger's earliest published works using brackets to denote pedalling, including The Sussex Mummers' Christmas Carol and Irish Tune From County Derry (both Schott, 1911). Apparently Grainger at first mistrusts the accuracy of the brackets, since he employs vertical lines, not sporadically, as in works from the 1920s onwards, but for every pedal change (example 6).

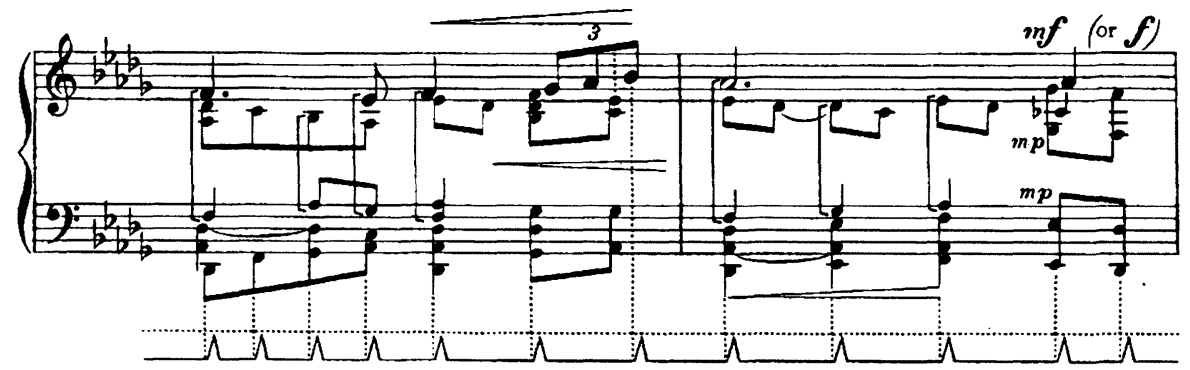

Example 6: The Sussex Mummers' Christmas Carol, bars 3-4. Copyright (C 1944 (renewed) by $\mathrm{G}$. Schirmer, Inc. (ASCAP). International copyright secured. All rights reserved. Reprinted by permission.

That the pedal is to be changed just after the beat is thereby made perfectly clear, although it is difficult to imagine anyone playing these works not using syncopated pedalling even if it were not indicated. In his book The History of Pianoforte Pedalling, David Rowland notes that "some composers have gone 
to great lengths to ensure that pedalling is as clear as possible" and cites Irish Tune from County Derry as an example. He goes on to explain that this work "demonstrates at least one reason why more music does not contain detailed pedalling-it takes a lot of space and adds considerably to the cost of printing." 9

The originality of Grainger's pedal notation of course mirrors the originality of his pedal technique. Grainger not only used the pedals in new ways, but the contexts in which he employed the pedals, and the uses to which he applied them, also attest to a unique creative spirit.

Sometimes, changes in pedalling from one context to another are occasioned by purely practical concerns. In Country Gardens, for example, the "violently wrenched" arpeggiated chords in mm. 41-42 are each pedalled; when the same passage occurs an octave lower in mm. 73-74, the markings are altered to "wrenched but short" and "no pedal," in part, no doubt, to compensate for the increased sonority in the lower octave. Something similar occurs in Colonial Song, where the tonic 4-3 resolution in the alto voice at $\mathrm{m}$. 22 is clouded by the damper pedal. When the same passage occurs with a thickened texture at $\mathrm{m}$. 30, Grainger indicates that the resolution to the tonic $6 / 4$ chord is to be cleanly pedalled (example 7).

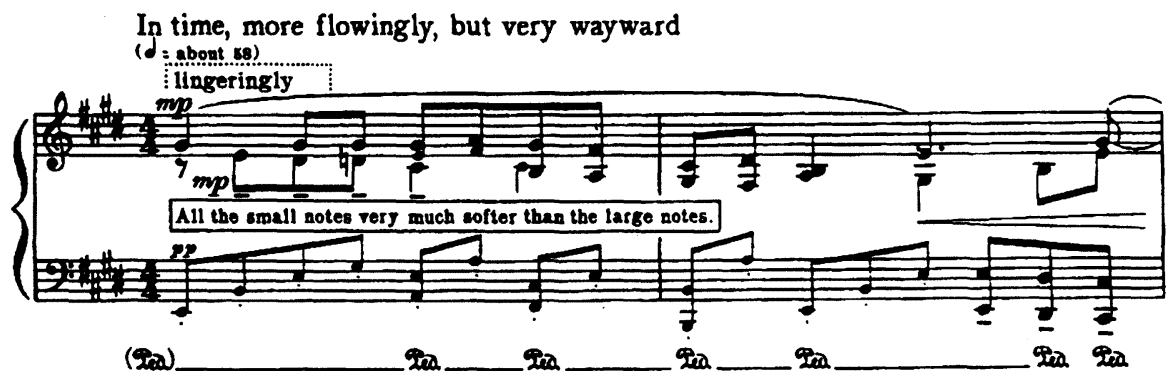

Example 7a: Colonial Song, bars 21-22. Copyright @ 1928 (renewed) by G. Schirmer, Inc. (ASCAP). International copyright secured. All rights reserved. Reprinted by permission.

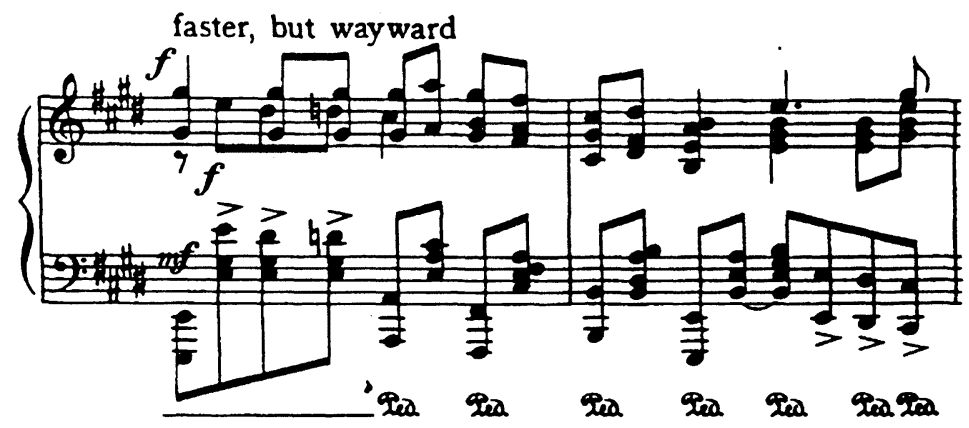

Example 7b: Colonial Song, bars 29-30. Copyright 수 1928 (renewed) by G. Schirmer, Inc. (ASCAP). International copyright secured. All rights reserved.

9 David Rowland, The History of Pianoforte Pedalling (Cambridge: Cambridge University Press, 1993), 132. 
The process is later reversed; a new pedal is assigned to the tonic $6 / 4$ chord on the second beat of $\mathrm{m}$. 38, but not when the passage recurs with a different voicing at $\mathrm{m}$. 43. In this way, the presence or absence of the damper pedal is used to create contrasts between otherwise similar or identical passages.

Another example of innovative pedalling occurs earlier in Colonial Song. At $\mathrm{m} .8$ the tenor of the tonic $6 / 4$ chord is held while the other voices are given a sixteenth rest; Grainger indicates that the pedal is to be held through this rest. At the close of the next phrase, this time a perfect cadence at m. 11, the tenor is not held so that rests occur in all parts. Here Grainger takes pains to ensure that the pedal is released, using both a pedal asterisk and commas to elucidate the phrasing (example 8).

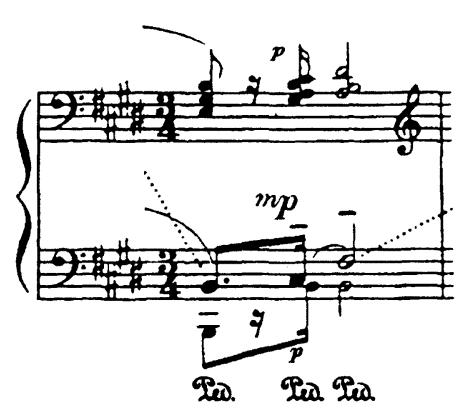

Example 8a: Colonial Song, bar 8. Copyright (C) 1928 (renewed) by G. Schirmer, Inc. (ASCAP). International copyright secured. All rights reserved. Reprinted by permission.

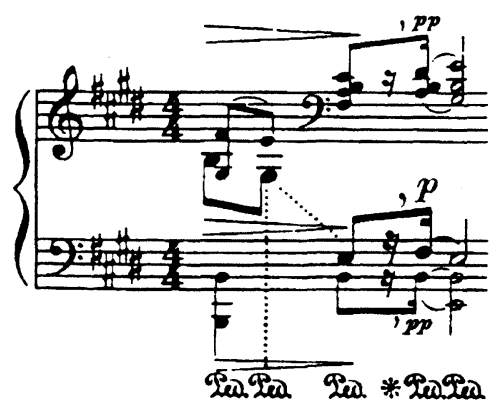

Example 8b: Colonial Song, bar 11. Copyright $(1) 1928$ (renewed) by G. Schirmer, Inc. (ASCAP). International copyright secured. All rights reserved. Reprinted by permission.

In instances where a pedal change is not called for, but where one's natural inclination would be to change the pedal, Grainger makes his intention evident by 1 ) assiduously marking the pedalling when otherwise pedalling is left to the performer's discretion, or 2) by using a horizontal solid or dotted line after the stylized Ped. to denote that the pedal is to remain depressed. An example of 1) occurs in Handel in the Strand, where Grainger indicates that the pedal is to be held through the chord changes at mm. 28 and 73 (example 9).

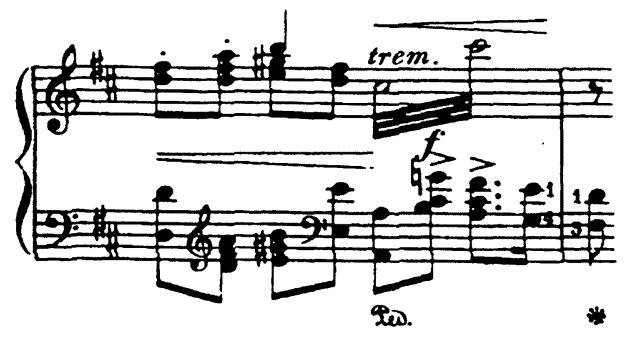

Example 9: Handel in the Strand, bar 28. Copyright (C) 1930 (renewed) by G. Schirmer, Inc. (ASCAP). International copyright secured. All rights reserved. Reprinted by permission. 
An example of 2) occurs in a striking passage at the end of Colonial Song, where two arpeggiated secondary dominant chords a semitone apart are pedalled together to create an especially rich sonority (example 10).

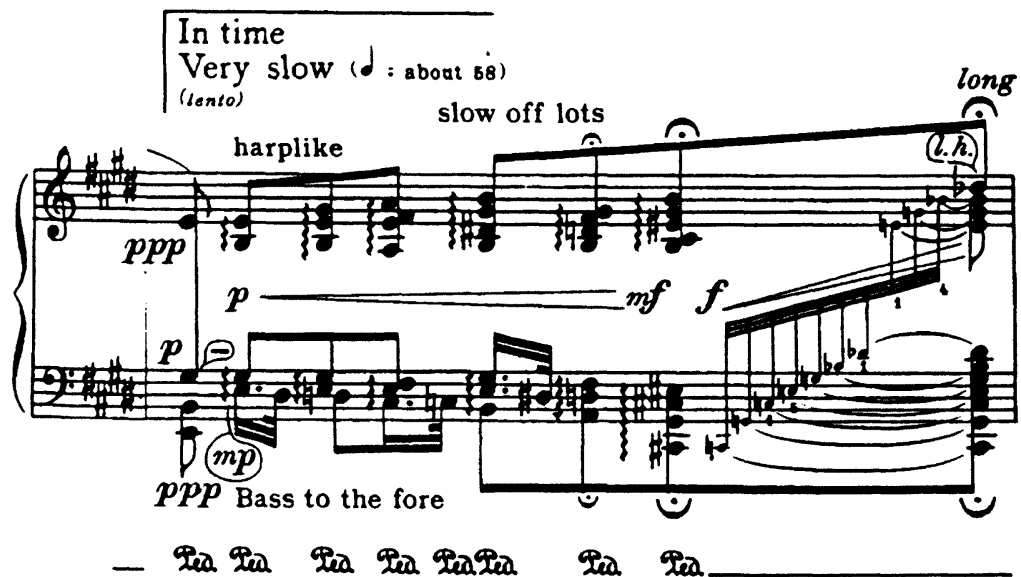

Example 10: Colonial Song, bar 66. Copyright @ 1928 (renewed) by G. Schirmer, Inc. (ASCAP). International copyright secured. All rights reserved. Reprinted by permission.

On a grander scale, in Spoon River the damper pedal is used to create a wash of colour. Grainger uses a horizontal dotted line to indicate that the pedal is to be held from m. 51 to m. 65 , and the admonition to "keep it $p p$," marked in m. 58 , is one of the piece's technical challenges.

Grainger sometimes requires the damper pedal to be held through non-legato or staccato passages. Jospeh Rezits, a Grainger pupil, reports that his teacher "preferred non-legato to legato in passagework. Non-legato, even when pedal was used, produced a more controlled sound and more equality in volume levels." 10 That this applied to more than just passagework is evident in Colonial Song, where in several instances the left hand is marked staccato (mm. 21-23, 25 and 55), but the damper pedal is to remain depressed. The same effect occurs many times in Eastern Intermezzo (mm. 20, 22, 26, 28, 32, 64-65, 68-69, 72-73, and especially 80-97), and in "The Gumsuckers'" March (mm. 44-48), One More Day, My John (mm. 19-21) and the "easy version" of Dowland's Now, O now I needs must part (Schott/Schirmer 1937) (mm. 49-50).

Grainger also calls for successive forte pitches to be played with "bunched" fingers, and this necessarily non-legato fingering is frequently used in tandem with the damper pedal. Examples occur in Colonial Song in mm. 42 (both hands) and 47 (right hand) and in To a Nordic Princess in mm. 6-9 (right hand) and 44-51 (both hands) (example 11).

10Joseph Rezits, "Grainger the Pianist," in Lewis Foreman, ed., The Percy Grainger Companion (London: Thames Publishing, 1981), 179. 


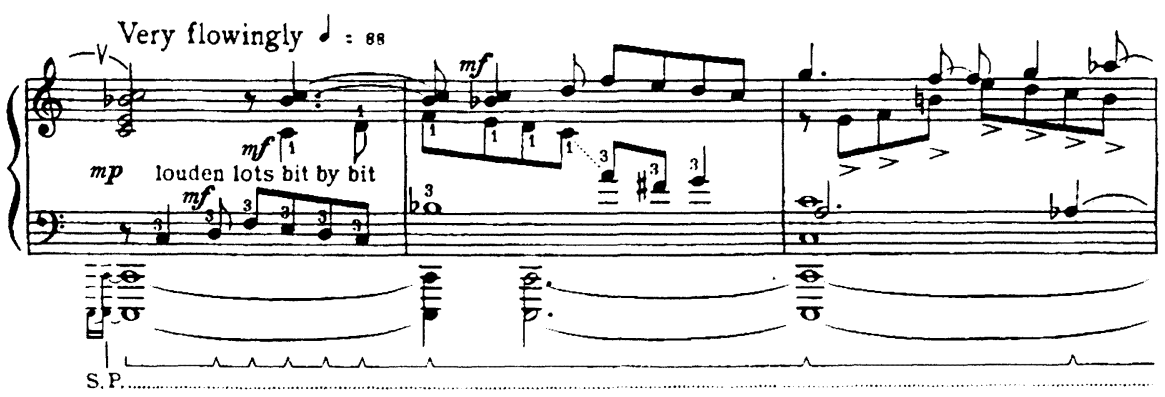

Example 11: To a Nordic Princess, bars 44-46. Copyright @ 1930 (renewed) by G. Schirmer, Inc. (ASCAP). International copyright secured. All rights reserved. Reprinted by permission.

In an interview with Harriet Brower, Grainger elaborated on the use of the damper pedal, discussing subtleties beyond mere legato technique.

When teaching piano, I make a great study of pedal effects with my pupils. Many fine effects of diminuendo can be made with quick half pedaling. The subject of pedaling is none too well understood; most wonderful tone colours can be produced by an artistic use of the pedals.

Brower goes on to explain that at this point

Mr. Grainger seated himself at the piano and played a brilliant passage ending with sustained chords, for which latter he used shifting, vibrating pedals with charming effect. ${ }^{11}$

At the very end of Colonial Song, half pedalling is used effectively in conjunction with pitches depressed silently and sustained by the damper pedal. In this manner, harmonics generated by the fortissimo arpeggio in $\mathrm{m} .67$ are allowed to ring freely in mm. 68 and 69 , but are gradually cleared by half pedalling. Half pedalling is also explicitly called for m. 62, but its use is essential at several unmarked points elsewhere in the work (example 12).

\section{The sostenuto and una corda Pedals}

Grainger "felt that the sostenuto pedal was generally overlooked by pianists and he used it frequently in his own pieces, as well as in the organ transcriptions and impressionist pieces he frequently performed." 12

There is much evidence that the use of the sostenuto pedal was one of Grainger's pianistic preoccupations and, during his summer classes at the Chicago Musical College, he usually devoted an entire class to it. Louise McDowell reports that in 1919 Grainger used Cyril Scott's Sonata in A minor

11 Harriette Brower, Piano Mastery: Second Series. Talks with Master Pianists and Teachers (1916; rpt. New York: Frederick A. Stokes Company, 1917), 9-10; rpt. as "An Interview with Percy Grainger" in Lewis, A Source Guide to the Music of Percy Grainger, 18.

12Karl Payne, "Percy Grainger as Teacher," Clavier 21, no. 9 (1982): 14-15; rpt. in Lewis, A Source Guide to the Music of Percy Grainger, 14. 


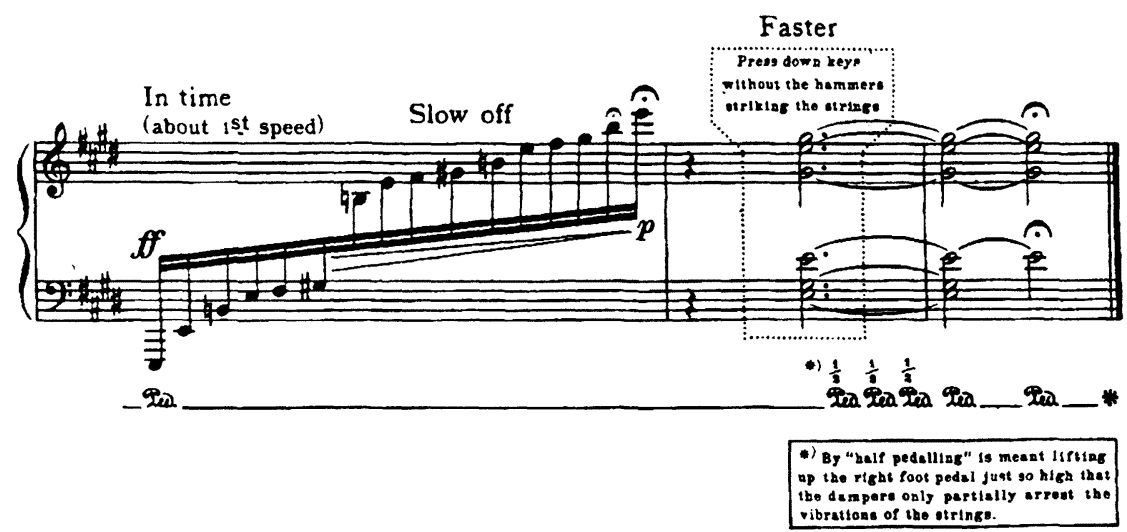

Example 12: Colonial Song, bars 67-69. Copyright $(\mathcal{1} 1928$ (renewed) by G. Schirmer, Inc. (ASCAP). International copyright secured. All rights reserved. Reprinted by permission.

to illustrate its use..$^{13}$ Albert Golding recalls that during classes two or three years later Grainger "took great delight in all the tricks he had devised for the ... sostenuto pedal,"14 and John Bird reports that again in 1925 "special emphasis was laid [on its use]." 15

Alma Brock-Smith, who studied with Grainger at the Chicago Musical College in 1928 and who heard him in concert both before and after that time, couldn't recall him teaching the sostenuto pedal specifically, but was aware of it in his playing: "I was inclined to watch his foot occasionally to see what he was doing. . . . In the Grieg Concerto Grainger [made] full use of the sostenuto and ... gloried ... in the result."16 She speculated that "Grainger's work on Bach, maybe thinking of Bach as an organist" had influenced his use of the sostenuto pedal, a point on which Ronald Stevenson concurs:

The fons et origo of Grainger's use of the middle pedal was Section 4 of the First Appendix to Volume I of the Busoni edition of Bach's Well-Tempered Clavier: "On the Transcription of Bach's Organ-works for the Pianoforte." In the summer of 1903 Grainger studied Bach-Busoni transcriptions with Busoni in Berlin, and the use of the middle pedal would certainly be an integral part of those lessons. ${ }^{17}$

Stevenson further claims that "Grainger was the only Busoni pupil who developed fully his master's technique of middle-pedalling." 18

13Louise McDowell, Past and Present: A Canadian Musician's Reminiscences (Kirkland Lake, Ont.: n.p., [1957]), 116.

14 Albert Goldberg, "Percy Grainger: A Recollection," The Grainger [Society] Journal 7, no. 2 (1985): 15-19; rpt. as "Some Grainger Impressions" in Lewis, A Source Guide to the Music of Percy Grainger, 21.

15John Bird, Percy Grainger (London: Paul Elek, 1976), 191.

16Brock-Smith, personal interview, 15 March 1995.

17Ronald Stevenson, "Grainger and the Piano," in Foreman, ed., The Percy Grainger Companion, 117. 18 Ibid., 117. 
It was Grainger's contention that the sostenuto pedal

... acts as a clarifying and refining influence upon piano playing, making unnecessary (and inexcusable) many blurred pedalled passages formerly condoned and raising considerably our whole pianistic standard of harmonic cleanliness. The [sostenuto] pedal is almost as necessary to modern pianism as is the damper pedal, and no pianist can pretend to be properly equipped who has not mastered [its use]. ${ }^{19}$

When the sostenuto pedal is to be used, Grainger generally facilitates matters by providing a grace note or two during which the pedal can be engaged before the beat. Examples occur in most of Grainger's piano works, including Eastern Intermezzo (mm. 52, 56, 66 and 98), The Immovable Do (mm. 36 and 62), Irish Tune From County Derry (m. 12 and 29), Colonial Song (m. 35), and To a Nordic Princess (mm. 12, 31, 32, 44, 50 and 57), and in the concert versions of the aria "Schafe können sicher weiden" from Bach's Cantata No. 208, called Blithe Bells by Grainger (Schott/Schirmer, 1931) (mm. 16, 45 and 54), of Dowland's Now, O now, I needs must part (Schott/Schirmer, 1937) (mm. 40, 60 and 67) and of Gershwin's The Man I Love (Harms Inc., 1944) (m. 36) (example 13).

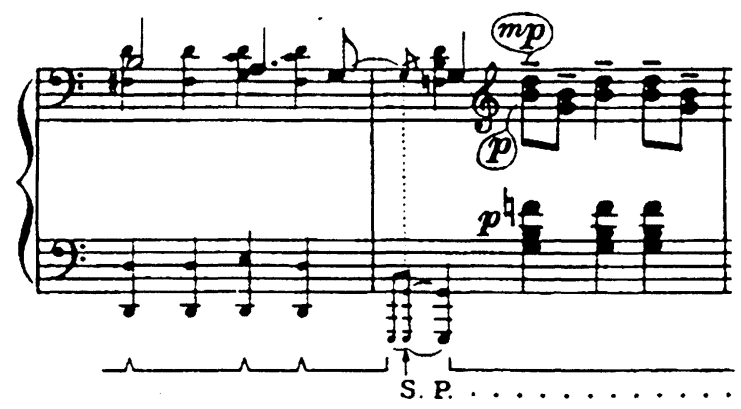

Example 13: Blithe Bells, bars 15-16. Copyright (C) 1931 (renewed) by G. Schirmer, Inc. (ASCAP). International copyright secured. All rights reserved. Reprinted by permission.

As noted earlier, the sostenuto pedal is also used to sustain notes that have been depressed silently, either to allow harmonics generated by previous pitches to ring freely (example 12 above), or to allow for harmonics to be generated by subsequently "sounded" pitches. Examples of the latter use occur at the beginning of Eastern Intermezzo and of the "free setting" of Brahms's Cradle-Song (Schott/Schirmer, 1923), as well as in mm. 140-143 of Jutish Medley (example 14).

The use of the damper pedal to contrast transposed or otherwise similar passages has a correlative in Grainger's use of the sostenuto pedal. At m. 56 $280-81$.

19Grainger, Guide to Virtuosity; rpt. in Lewis, A Source Guide to the Music of Percy Grainger, 


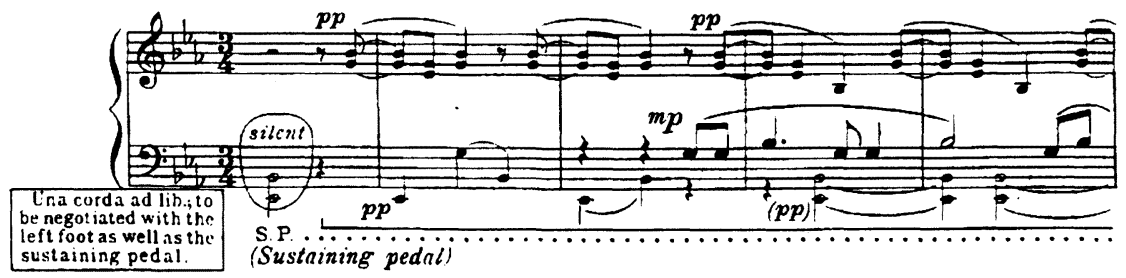

Example 14: Brahms-Grainger, Cradle Song, bars 1-5. Copyright (C) 1923 (renewed) by G. Schirmer, Inc. (ASCAP). International copyright secured. All rights reserved. Reprinted by permission.

of Colonial Song, a grace note, sustained from the preceding beat, makes it possible to depress the sostenuto pedal before the third beat. When this passage recurs two measures later, reharmonized, the grace note is omitted since the sostenuto pedal is not used (example 15).

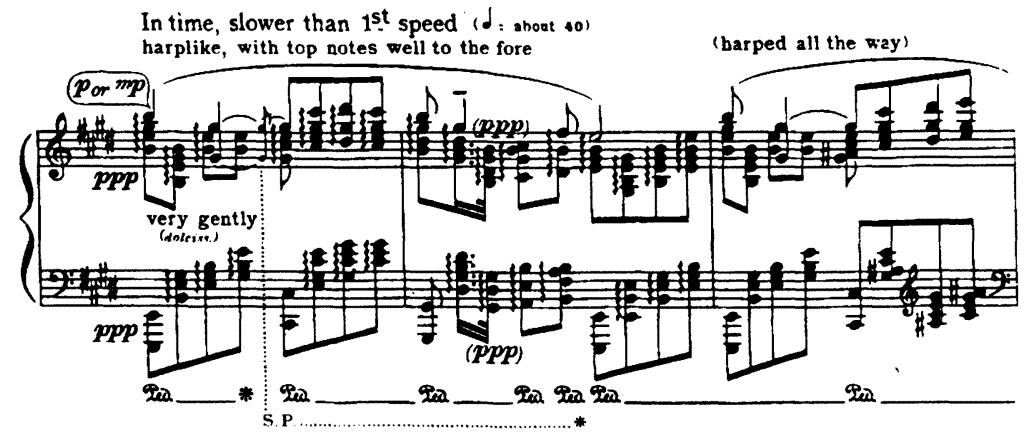

Example 15: Colonial Song, bars 56-58. Copyright () 1928 (renewed) by G. Schirmer, Inc. (ASCAP). International copyright secured. All rights reserved. Reprinted by permission.

At m. 59 of the same work, Grainger is clear that the sostenuto pedal is to be depressed, not with the grace note, but on the beat, in order to catch the left-hand octave. While on the face of it mm. 56 and 59 appear similar, the sostenuto pedal is employed with differing results (example 16).

As was true of the damper pedal, Grainger's fastidiousness with respect to the sostenuto pedal is evident in the precision of his notation. At the beginning of his setting of One More Day, My John (Schott, 1916) and in "The Gum-

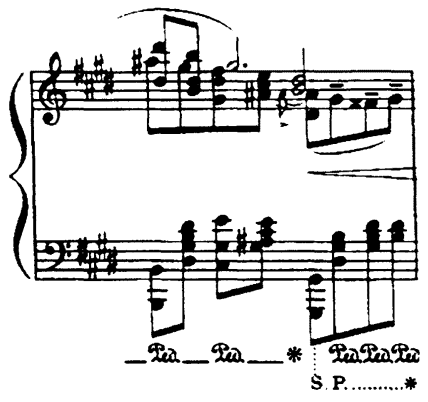

Example 16: Colonial Song, bar 59. Copyright 891928 (renewed) by G. Schirmer, Inc. (ASCAP). International copyright secured. All rights reserved. Reprinted by permission. 
Suckers" "March (mm. 67, 68, 93, 98 and 171) he surrounds the relevant pitches with dotted boxes and gives a written instruction that the pianist is to hold these notes with the sostenuto pedal. In two passages in Molly on the Shore (at mm. 95 and 126), Grainger supplies an alternate reading to be used "If your piano has a sustaining (middle) pedal. ..."Written instructions again clarify Grainger's intention (example 17).

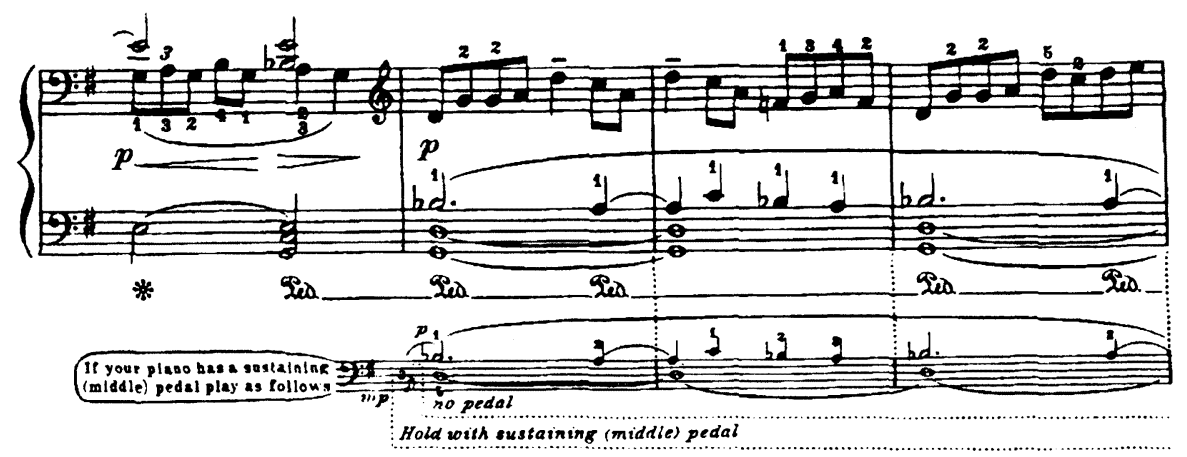

Example 17: Molly on the Shore, bars 94-97. Copyright (C) 1911 (renewed) by G. Schirmer, Inc. (ASCAP). International copyright secured. All rights reserved. Reprinted by permission.

In some works, Grainger uses tied notes to clarify his pedalling. At m. 21 of To a Nordic Princess he notates the last half-beat in the right hand as tied sixteenth notes, rather than a single eighth note, to make clear that the sostenuto pedal is to be depressed half-way through the beat. The same technique of using tied notes to clarify pedalling occurs in Jutish Medley at m. 68, To a Nordic Princess at m. 95, Blithe Bells at m. 62, Scotch Strathspey and Reel at m. 95, and The Immovable Do at m. 93 (example 18).

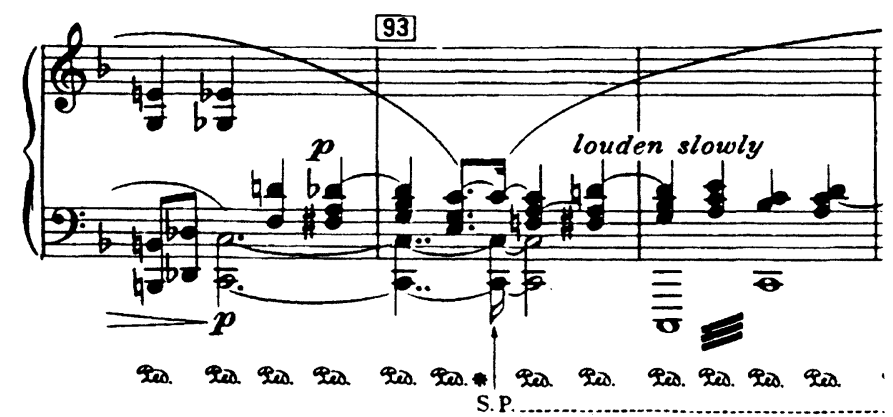

Example 18: The Immovable Do, bars 92-94. Copyright (C) 1941 (renewed) by G. Schirmer, Inc. (ASCAP). International copyright secured. All rights reserved. Reprinted by permission. 
Grainger employs another means of notation, in a more complex context, in Colonial Song at m. 17. Here, stemless notes are used to show that the sostenuto pedal is to be depressed only after the damper pedal has been released, so that only the left-hand octave and not the left-hand chord will be sustained (example 19).

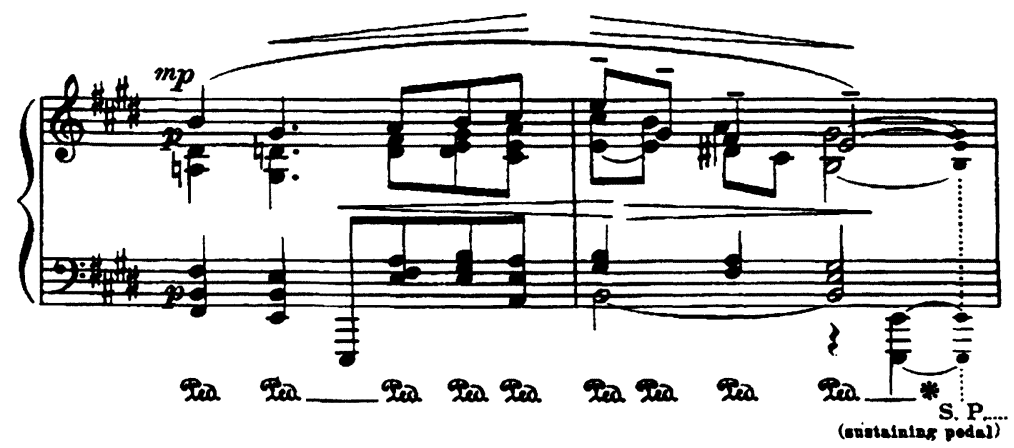

Example 19: Colonial Song, bars 16-17. Copyright (C) 1928 (renewed) by G. Schirmer, Inc. (ASCAP). International copyright secured. All rights reserved. Reprinted by permission.

Stemless notes are also used to indicate sustained pitches in Jutish Medley at mm. 33 and 164 (example 20).

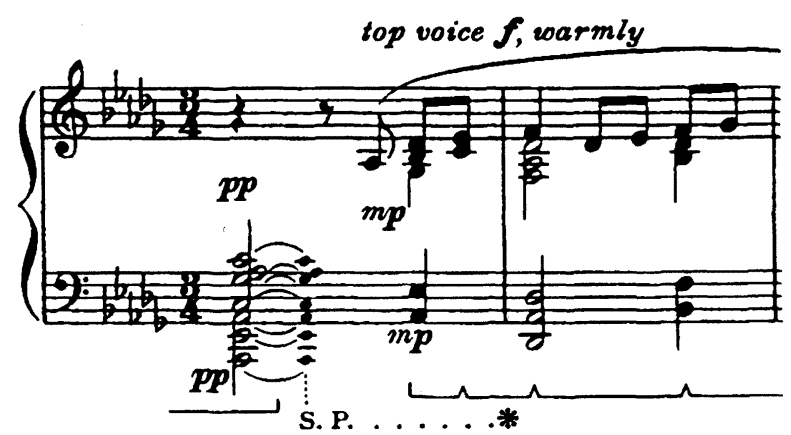

Example 20: Jutish Medley, bars 33-34. Copyright (C) 1930 (renewed) by G. Schirmer, Inc. (ASCAP). International copyright secured. All rights reserved. Reprinted by permission.

Grainger believed that the "properly equipped" pianist should master, not only each pedal individually, but "the joint use of all three pedals and their interplay with each other." 20 He provided a "Left Foot Study" in his Guide to Virtuosity incorporating simultaneous use of the sostenuto and una corda pedals, with the left foot "slewed round so that the toe of the foot faces the damper pedal and the heel of the foot faces away from the player, to his left." 21 
In this way, both the sostenuto and una corda pedals could be operated with the left foot, leaving the right foot free for the damper pedal. Grainger maintained that this technique "is an absolute necessity to modern pianism" (italics Grainger's). ${ }^{22}$ To ensure its use in his setting of Brahms's Cradle Song he appended a note at the beginning: "Una corda ad lib.; to be negotiated with the left foot as well as the sustaining pedal." Grainger may well have learned this technique from Busoni. Edward Weiss reports that in the trio section of Chopin's Scherzo in C-sharp minor, op. 39, Busoni sustained the chords beneath the leggierissimo figuration by using the sole of his left foot, while the heel depressed the una corda pedal. Busoni would then "shade and colour the descending passages" with the damper pedal. ${ }^{23}$

At the end of To A Nordic Princess, notes caught by the sostenuto pedal can be taken over by the damper pedal, thereby freeing the left foot for the una corda pedal. The sostenuto pedal is called for at m. 95 , but since the sustained pitches can be picked up by the damper pedal at m. 99, the left foot can be moved over to the una corda pedal for the pppp tremolando in the closing three measures (example 21).
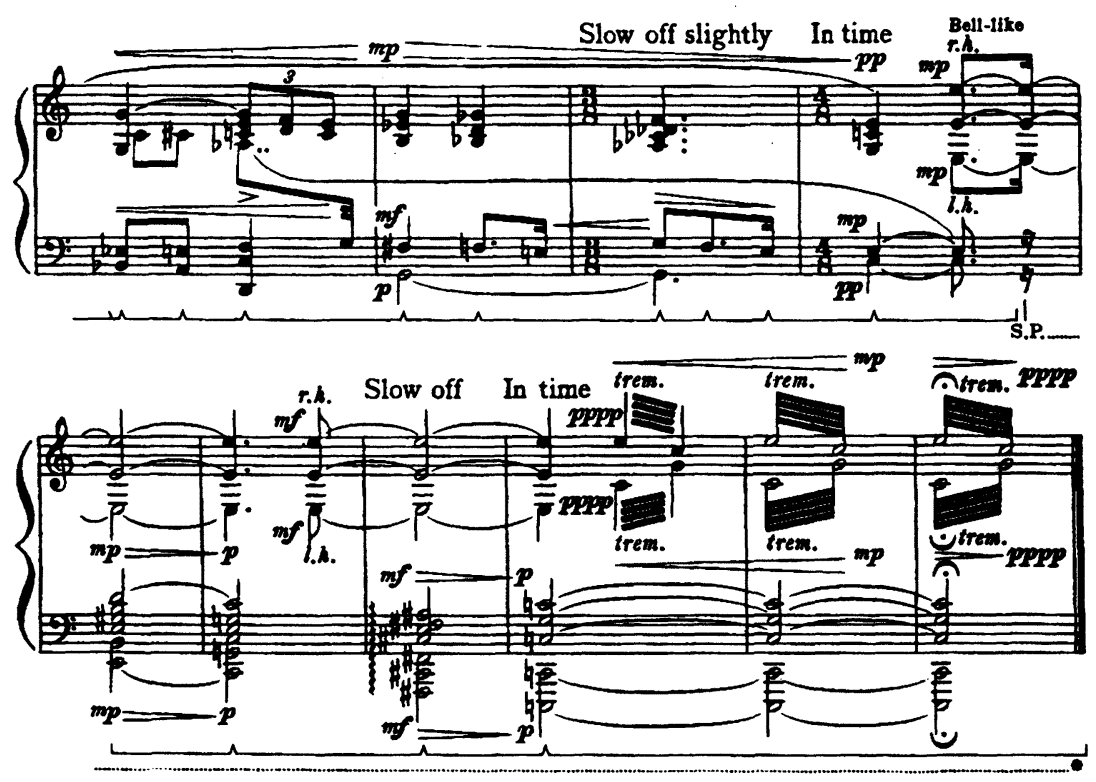

At this point the left foot may be moved from the sostenuto pedal to the una corda pedal.

Example 21: To A Nordic Princess, bars 92-101. Copyright (C) 1930 (renewed) by G. Schirmer, Inc. (ASCAP). International copyright secured. All rights reserved. Reprinted by permission. 
Only in exceptional circumstances is the use of the una corda pedal indicated by Grainger. ${ }^{24} \mathrm{He}$ did, nonetheless, condone its frequent use. Dorothy Payne, who studied with Grainger at the Chicago Musical College in 1929 and who participated elsewhere in several master classes, recalls that the una corda pedal "was used in most $p$ and all $p p$ passages." 25 Grainger himself explained that

As the soft pedal on modern pianos no longer carries with it any characteristic tone-quality (as it did on ancient pianos) and has, therefore, ceased to be a "special effect," it may be freely used wherever soft effects are desired; the more so when playing upon large-toned pianos. ${ }^{26}$

Joseph Rezits reports that Grainger himself used the una corda pedal "for reasons other than merely making the sound softer; that is, to produce qualitative modifications in louder sections." 27 Ronald Stevenson agrees that "Grainger used the 'soft' pedal not only in piano but in forte [passages], just as Grieg achieved repressed passion in writing for string orchestra by using mutes in forte passages." 28

For more information concerning Grainger's use of the pedals, the reader is referred to the composer's own writings on the topic, particularly his Guide to Virtuosity, and is encouraged to scrutinize carefully the scores themselves. As John Bird has written,

... keys to the spirit of Grainger lie in the instinctive use of sensitive phrasing, sympathy for the subtleties of his counterpoint, and a spontaneous exuberance derived from cross-rhythms, syncopation and a general rhythmic "snap." Though in the end these things can hardly be taught, one is given every help in page after page of his scores, which bristle with meticulously detailed instructions and suggestions which, if understood, show that at least Grainger knew exactly what he wanted as regards, sound, atmosphere and feeling. ${ }^{29}$

Grainger's pedal markings are among these "meticulously detailed instructions" and are an invaluable aid for the pianist who wishes to convey both the sum and substance of Grainger's compositions. Such techniques as clearing accumulated sonorities by careful half pedalling, using the una corda pedal in certain forte passages, or varying the pedalling in otherwise parallel constructs, are the stock-in-trade of most fine pianists. Less usual is the carefully coordinated simultaneous deployment of the una corda, sostenuto and damper pedals. What is outstanding, however, is the extent to which Grainger notates what he

24Notably in his edition of Grieg's Piano Concerto (New York: G. Schirmer, 1920), where markings which Grieg himself wrote into Grainger's score or techniques which Grainger noted in Grieg's own playing of the work, are reproduced (e.g. I/mm. 42 and 140).

25Dorothy Payne, "Grainger the Teacher," in Foreman, ed., The Percy Grainger Companion, 185-86.

26Grainger, Guide to Virtuosity; rpt. in Lewis, A Source Guide to the Music of Percy Grainger, 282.

27 Rezits, "Grainger the Pianist," 182.

28 Stevenson, "Grainger and the Piano," 117-18.

29John Bird, "Grainger on Record," in Foreman, ed., The Percy Grainger Companion, 192. 
and other pianists might have instinctively done, but which few composers have even attempted to convey with any real accuracy. By observing carefully all of Grainger's markings, not the least of which pertain to pedalling, the diligent pianist may capture both the letter and spirit of Grainger's unique contributions to the literature of the piano.

\begin{abstract}
Eminent pianist and composer Percy Aldridge Grainger (1882-1961) filled his original music and folksong arrangements with detailed, though idiosyncratic instructions to performers. The extent to which his own meticulous pedal technique is mirrored in careful directions to pianists is both unusual and revelatory. Grainger's scores are examined here from the standpoint of the damper, sostenuto and una corda pedals. Numerous musical examples serve two purposes: 1) they give information concerning the complexity of Grainger's pedal technique and 2) they exhibit the array of notational methods the composer employed, at various stages in his career, to enable performers to replicate as nearly as possible his own scrupulous pedalling. As well, by examining in detail this one aspect of Grainger's rich artistry, light is shed on the relationship between composer and performer, and notation and interpretation, that Grainger sought to understand and articulate ever more clearly throughout his career.
\end{abstract}

\title{
Résumé
}

L'éminent pianiste et compositeur Percy Aldridge Grainger (1882-1961) a couvert les pages de ses arrangements de musique inédite et de chansons de folklore d'instructions détaillées, quoique idiosyncratiques, à l'intention des interprètes. Il est à la fois inhabituel et révélateur que sa technique consciencieuse de la pédale se révèle autant dans ses minutieuses directives à l'intention des pianistes. Les partitions de Grainger font ici l'objet d'un examen sous l'angle des pédales forte, de prolongation et douce. Les nombreux exemples musicaux remplissent deux objectifs: 1) ils renseignent sur la complexité de la technique de pédale de Grainger; et 2) ils démontrent l'éventail des méthodes de notation que le compositeur a employées à divers moments de sa carrière, pour permettre aux interprètes de reproduire le plus fidèlement possible ses propres utilisations scrupuleuses de la pédale. De plus, l'examen approfondi de cet aspect particulier de la riche maîtrise de Grainger jette un éclairage sur la relation entre compositeurs et interprètes, ou notation et interprétation, que Grainger a cherché à comprendre et à énoncer toujours plus clairement au cours de sa carrière. 